\title{
Socioeconomic Status of Nepalese Employed Women in institutional Sector: A Sociological Study of Dharan Sub-Metropolitan City
}

\author{
Bigyan Sharma ${ }^{1} \&$ Rakhi Verma ${ }^{2}$ \\ ${ }^{1}$ Principal Author \\ Lecturer \\ Department of Sociology, Prithivi Narayan Campus Pokhara, Tribhuvan University, Nepal \\ biggyan.sharma@prnc.tu.edu.np \\ ${ }^{2}$ Co-author \\ Lecturer \\ Department of Sociology, School of Engineering and Technology, Biratnagar, PU, Nepal \\ rakhivermasrivastav@gmail.com \\ DOI: https://doi.org/10.3126/dristikon.v11i1.39132
}

\begin{abstract}
Gender role has been changing in Nepali society. Traditional rigid patriarchal system has been changing gradually. Particularly urban society has realized such change. Women have marched towards the breadwinning job which was assumed to be the job of male member in traditional society. This research article is dedicated to the understanding of the condition of dual role of working women and increasing socioeconomic status of urban society. This article is based on the primary data. Online questionnaire has been used as the main tool for data collection. Obtained data were analyzed by using the SPSS program. Result of this study shows that there is the situation of double burden of household chores and income generating work of outer periphery. They are facing different physical, mental, social difficulties in both sectors' work. However, their socioeconomic status has been changing positively in society along with the changing gender role in the urban society.

Keywords: working women, dual role, socioeconomic status, household chores, urban area

\section{Introduction}

Gender is the socio-cultural and psychological difference between male and female in society. 'The term gender has been used since early 1970s to denote culturally constructed 'feminity' (Jackson, 1998, p. 131). It is socially constructed. 'One is not born woman but become one' (Beauvoir, as cited in Jackson, 1940, p. 132). Society and culture assign individuals in their respective gender role on the basis of their biological sex. Generally, in patriarchal society male are assigned in the breadwinning job where as women are assigned household chores.
\end{abstract}


The present society is divided into several layers. On the one side hierarchical division of society contributes to the smooth functioning of society and on the other side, it is creating disparity among male and female (Macionis \& Plummer, 2014). It is stratified and marked by inequality based on several dimensions. Out of several dimensions, gender is an important base of social stratification and inequality in society.

Society is characterized by the gender inequality world widely but there is variation in the rate of inequalities according to the time, place, and community (Macionis \& Plummer, 2014). The traditional division of labour is creating various types of inequalities between men and women. However, the scenario has been changed. Both male and female categories are capable of learning and doing activities of each other's socially assigned gender role (Schaefer, 1994).

The gender role played by men and women has also been changed in society. It is important that how can we alter the gender role in society (Mogford et al., 2015). Modern education, expansion of capitalist economy, development of city, industrialization, legal provisions, and social movements are responsible factors for bringing change in gender role. The steps of Nepali women are marched towards the income generating activities in governmental, private and nongovernmental sector. It is upgrading the socioeconomic status of Nepalese working women. However, an important issue need to be considered is that their role in household is not decreasing significantly in comparison with the increasing rate of involvement in payable work. It shows that they are becoming the victim of double burden of household chores and income generating job. Gynawali (2017) observes, "The more time the household works demand the more stressed working females are" (p. 28). It means another form gender inequality is rising in Nepali society. It is assumed that this type of dual role situation decreasing the work efficiency women. This situation of involving in dual works is mostly found in the urban of Nepali. Another issue to be considered is that outlook of Nepali society has changed rapidly. However, the patriarchal norms and values are not changed significantly. Thus, in this research article, researcher tries to the real situation of Nepalese women.

\section{Statement of Problems}

Gender roles in Nepali society have been changing gradually. Women are moved into the income-generating job. It is the result of the effort made by the Government, private sector, NGOs-INGOs, and Civil Society. However, they are still performing their traditional gender role. This study is based on the assumption that the socio-economic status of working is increasing positively but their dual role is also creating problem to them. A number of research studied have been conducted in the field of Gender and socioeconomic status of working women of the society. In the context of Nepal, there are few studies which are devoted to status 
of women and their burden of dual works.. This study is dedicated to add information about the dual role played by working women and their socioeconomic status. This article is trying to answers the following research problems:

- What is the experience of working women about their dual role in society?

- What is the socio-economic status of working women?

\section{Research Objectives}

The general objective of this study is to describe the impacts of changing gender roles on the socio-economic status of working women of Nepali society. This study has set the following special objectives:

- To explore situation of dual role of working women in Nepali society.

- To describe the condition of the socio-economic status of working women.

\section{Literature Review}

Several research works have been conducted in the field of gender roles and the socioeconomic status of women in society. This study is centered on several gender issues in society. Some works have been reviewed in these studies are as follows:

\section{Integrative Review}

Acharya and Ghimire (2005) argue that socio-cultural exclusion and empowerment and social inclusion are the twin process of gender mainstreaming. Women must have the freedom and develop the ability to make decisions about their work and other life options. Women's inner peripheral activities are not still taken as important for smooth running of family. Similarly, poor households give permission women to work in a public periphery as wage labor. Likewise, gender equality must be understood in terms of life options determined by the "material assistance, gender ideology and socio-economic structures" (p. 4726). This article suggests that gender relations must be understood in terms of multiple measures such as economic, political, social and cultural measures to understand women's socio-economic condition.

Very few numbers of women are involving in income-generating public peripheral activities. There is still the practice of male-centered social roles in organized sectors of society. Male worker are gaining a superior position and the role of women workers is subordinated to male workers. Similarly, it is believed that this male-dominated situation is influenced by traditional gender roles determined by patriarchal values and there is a need to change cultural practices towards gender roles (Gupta, 2006). However, it is necessary to see the role and position of working women in work place to understand their real situation. Thus, my study is trying to cover the socio-economic status of women in both organized and unorganized sectors. 
Society is changing drastically. It is the result of increasing women workforce in paid able job. Similarly, women's access has been increased in various sectors. They are marching towards payable work by rupturing the traditional conceptions of work. But, they are not giving up their traditional gender role. Similarly, most working women are suffering from difficulties to perform the dual role of household activities and changing gender roles in the public periphery (O'Connell, 2007).

Bushell (2008) argues that there are women entrepreneurs and their number is increasing day by day. With the growing number of women entrepreneurs, they are facing different challenges in their respective sectors of entrepreneurship. Similarly, traditional patriarchal values dominated traditional gender roles, lack of appropriate educational and financial opportunities are the main challenges of women entrepreneurs. But also, those challenges provided them an appropriate employment environment "to create their own work environment; to circumvent poverty and gain confidence, courage and independence" (p. 534).

Khan and Khan (2009) opine that there is no security and protection of women workers, and they are deprived of benefit in women's activities. Women workers of informal sectors are from poor families and are more suffered from poverty than working women in formal sectors. They conclude that women workers are taking the financial load of their families also. Similarly, they are performing the nurturing and caring functions of their family also. It shows that women are veering the double burden. Women, "working in informal sectors of the economy, are mainly contributing to household budget due to the pressure of unmet household budget" (Khan and Khan, 2009, p. 90). This study shows the real conditions of working women that they are performing the role of household as well as performing breadwinning job.

Warren (2010) argues that women's employment has changed the gender roles. Change has given recognition to double income families. The economic status of women determines women's resistance to their subordinations. Autonomy for both men and women contributes to the stability and solidarity of families. Women, in modern society, are doing the job of income generation due to the different causes such as an expansion of road, communication, electrification, urbanization, and educations. Their status has been improving. However, gender inequality remained in various sectors of society. They are accepting the traditional beliefs towards gender roles in south Asia (Blunch \& Das, 2015).

Moaddel (2020) assumes that gender-bias behaviour toward women is the main obstacle to develop a gender-egalitarian society. The social order is not possible without gender equality. Similarly, this book talks about attitudes towards gender in Indian society, European society, and the Middle East and North African countries. Similarly it shows that in the Middle East and North African countries, Women are ranked subordinated class. Current gender 
disparity is the cause of unequal wage work. All social institutions are developed by malecentered values. There is more gender equality among young, educated individuals. Further it shows that there is a lower socio-economic status of women in conservative families and society.

The literature reviewed above is from different periods and from different countries. These studies focus on the various aspects of gender inequality. Some focus on the informal sector and some other focuses on the formal sectors. In this study, I studied the socio-economic status of Nepalese working women from both the formal and informal sectors of society. This study depends on the insight provided by the reviewed literature.

\section{Theoretical Review}

There is a diversity of feminist thought and theories. All these theories are developed to analyze and explain the gender relationships in society and they are heading to the understanding of society from gender perspective. Review of theory underpinned in this article is given as follows:

Lengemann and Brantheley (2000) opine that feminist theory is a system of ideas created from the feminist stand point. These are women-centered theories because these theories focus on women, their situation, and experience. It treats women as 'subject' and 'object' of investigation. Out of several feminist theories, Liberal Feminism is an important theory to explain gender in society. Liberal Feminism focuses on gender inequality in different spheres of social life. It assumes that "women's location in most situations is not only different but also less privileged than or unequal to that of men" (p. 450). Liberal Feminism explains the gender inequality in terms of "the social construction of gender the gender division of labor, the doctrine and practice of public and private sphere, and patriarchal ideology" (p. 455).They suggest that equal distribution of social goods, change in law, equal distribution of educational and economic opportunities, equal responsibilities of family life, change the ways of agents of socialization, etc. are the major remedies to establish the gender-egalitarian society.

Johnson (2008) opines that standpoint theory is another feminist sociological theory which is developed by Dorothy Smith. Likewise this theory assumes that social life is experienced from a particular social position where social actors are located in the wider social structures. Thus, this study is mostly underpinned on the combination of liberal feminism and feminist standpoint theory. The rationale of choosing dual theory that researcher believes that single theory is not sufficient to understand the real gender roles and its impact on working women. This study is seeking gender roles and relationships from women's standpoint theory. 


\section{Materials and Methods}

\section{Research Design, Universe Sample and Data Collection Process}

Researcher has used the primary data in this research article. This article is primarily based on the principle of descriptive research design. Structure online questionnaire was used to collect the data. Google form has been used for the collection of data when preparing this research article. Dharan sub metropolitan city was used as the universe or population of study in this research. Due to the pandemic situation of COVID-19, the research was not able to collect the data physically. Thus to collect the online data, a cluster of Five hundreds Face book friends, who are permanently or semi permanently residents of Dharan of researcher was formed. Out of Five hundreds element of universe twenty percent or one hundred respondents were selected by using the simple random sampling and link of questionnaire listed in Google form was sent to them via either Face-book messenger or email as per the availability of respondents. Out of hundred, sixty nine questionnaire were returned back by respondents after filling it. .

\section{Data Analysis and Presentation}

Being a survey study, this research article is mostly based on the hard data which were collected by online questionnaire. This research article is of the quantitative nature. Data were manage and analyzed by using the SPSS software program. In this research article the result is presented in table and interpretation is made in the heading of discussion. In this research article changing gender of working women was analyzed as an independent variable and socioeconomic status and condition of double burden of household chores and income generating work of out from the household as dependent variables. Various indicators such as situation of dual role, help from the male member, community attitudes towards the working women, independency to spend their income, role of male and female in educating children, leadership in family and community etc. were examined to see the relationship between independent and dependent variables. This research was conducted on the basis of liberal feminism and standpoint theory.

\section{Ethical Consideration}

In course of conducting this research, researcher has faced a number of problems. The research period was highly afSected by the pandemic situation of COVID 19. Due to this world wide pandemic situation researcher restricted to limited respondents to collect data. Thus, online questionnaire was used to collect data which may have the several weaknesses. In this context I take the sole responsibility of weaknesses of this research process and article. Similarly, I am confidence that collected data are the reliable and valid. 


\section{Results and Discussion}

\section{Participant's Socio-cultural Characteristics}

In this study, an online questionnaire constructed in Google form was sent to 100 people living in Dharan sub-metropolitan area and its adjoining area through Facebook messenger. Out of 100, 69 have filled the questionnaire and returned it back. Out of 69 respondents, 28 were in the 20-30 age group, 25 in the 30-40 age group and 9 in the 40-50 age group and 2 in the 50-60 age group and 5 respondents did not mention their age.

Respondents have different characteristics when viewed on social and cultural grounds. On the basis of religion, there are 45 Hindus, 12 Kirat, 5 Buddhist, 3 Christians, 2 atheists, 1 Islam and 1 others respondents. Similarly, on the professional basis, there were 14 from civil service, nursing security etc., 2 from the business, 38 from the teaching service, 15 from other profession. There are 14 males and 55 female's respondents. Likewise, 26 people from Khas aarya, 36 respondents from ethnic groups, 4 respondents from Madhesi community and 3 from the Dalit community on the basis of caste and ethnicity. On the basis of educational qualifications, 3 from SLC or SEE, 9 from the certificate level or +2 level, 18 from the bachelor level, and 33 from post graduate level and 6 from above post graduate level respondents were participated in the study. On the basis of marital status, there are 48 married, 20 respondents were unmarried and 1 widowed respondent.

\section{Results}

The table 1 shows the employment status of women in family. Out of 69 respondents household $68.1 \%$ women are employed in income generating job and in 31.9 household women are not employed and they are only performing household chores. Higher number of women employment is associated with the urban needs and demands of people.

\section{Table 1}

Employment Status of Women in Family

\begin{tabular}{lcc}
\hline Response & Frequency & Percent \\
\hline Employed & 47 & 68.1 \\
Unemployed & 22 & 31.9 \\
\hline Total & 69 & 100.0 \\
\hline
\end{tabular}

Note. Online survey 2020.

Table 2 depicts the working areas of working women. Out of 47 women working household 38.3 percent women are working in the service sector which includes civil service, nursing, and security service. Similarly, $42.55 \%, 2.18 \%$, and $10.64 \%$ women are doing their 
in the teaching field, in business, and in other occupations respectively. Out of 47, $6.38 \%$ missed to respond their occupation.

\section{Table 2}

\section{Working Area of Women}

\begin{tabular}{lcc}
\hline Response & Frequency & Percent \\
\hline Service & 18 & 38.3 \\
Business & 1 & 2.18 \\
Teaching & 20 & 42.55 \\
Others & 5 & 10.64 \\
Missing & 3 & 6.38 \\
\hline Total & 47 & 100.0 \\
\hline
\end{tabular}

Note. Data are taken from online survey 2020.

Table 3 is related to the involvement of working women in household chores. Out of 47 working women $97.87 \%$ women are also involving in household chores. Likewise one working woman is not involving in household chores.

\section{Table 3}

Involvement in Household Chores

\begin{tabular}{lcc}
\hline Response & Frequency & Percent \\
\hline Yes & 46 & 97.87 \\
No & 1 & 2.13 \\
\hline Total & 47 & 100.0 \\
\hline
\end{tabular}

Note. Data are taken from online survey 2020.

Table 4 exhibits whether working women are taking rest after returning from employment or not. Out of 47 working women 44 women responded the question. Out of 44 , $47.72 \%$ working women are taking rest whereas 19 or $43.18 \%$ working women are not taking rest after returning from their work. Similarly, $9.1 \%$ working women are taking rest sometimes. In this question, missing cases are 3.

\section{Table 4}

Tiredness of Working Women

\begin{tabular}{lllll}
\hline Response & Frequency & \multicolumn{3}{c}{ Percent } \\
\hline Yes & & 21 & & 47.72
\end{tabular}




\begin{tabular}{lrr} 
No & 19 & 43.18 \\
Sometimes & 4 & 9.1 \\
\hline Total & 44 & 100.0 \\
\hline
\end{tabular}

Missing case $=3$

Note. Data are taken from online survey 2020.

Table 5 presents the physical tiredness of women who are working within the household and employed women. Out of 69 respondents, $68.1 \%$ women who are working in and outside the household are feeling physical tiredness and 22 or $31.9 \%$ who are working within household are not feeling physical tiredness.

\section{Table 5}

Physically tiredness of women who work within and outside household

\begin{tabular}{lcc}
\hline Response & Frequency & Percent \\
\hline Yes & 47 & 68.1 \\
No & 22 & 31.9 \\
\hline Total & 69 & 100.0 \\
\hline
\end{tabular}

Note. Data are taken from online survey 2020.

The table 6 presents the condition of help of male member in household chores. In course of collection of information the question about the help of male member of household. Out of $69,82.6 \%$ respondents opined that there is the situation of cooperation from the male member of society whereas 17.4 household male members do not help to female member in household chores.

\section{Table 6}

Help of Male Member

\begin{tabular}{lcc}
\hline Response & Frequency & Percent \\
\hline Yes & 57 & 82.6 \\
No & 12 & 17.4 \\
\hline Total & 69 & 100.0 \\
\hline
\end{tabular}

Note. Data are taken from online survey 2020.

The table 7 shows the situation of male/female role in teaching children. The study shows that $8.7 \%$ male are teaching their children at household. Similarly, $39.1 \%$ female 
members are playing crucial role in teaching children in household. Likewise $52.2 \%$ respondent opined that members who have time are teaching children in the family.

\section{Table 7}

Male/ Female Role in Teaching Children

\begin{tabular}{lcc}
\hline Response & Frequency & Percent \\
\hline Male & 6 & 8.7 \\
Female & 27 & 39.1 \\
Member who have time & 36 & 52.2 \\
\hline Total & 69 & 100.0 \\
\hline
\end{tabular}

Note. Data are taken from online survey 2020

The table 8 presents care giving function at the time of sickness. In $18.8 \%$ households male member of family takes sick member to the hospital where as in $26.1 \%$ household female members do that function and in $55.1 \%$ household member who have time takes sick member to the hospital.

\section{Table 8}

Who Takes Sick Member to Hospital?

\begin{tabular}{lcc}
\hline Response & Frequency & Percent \\
\hline Male member & 13 & 18.8 \\
Female & 18 & 26.1 \\
Individual who have time & 38 & 55.1 \\
\hline Total & 69 & 100.0 \\
\hline
\end{tabular}

Note. Data are taken from online survey 2020.

The table 9 shows the situation of division making in a family. This study shows that out of 69 households $18.8 \%$ are the male decision maker where as in $10.1 \%$ household female are in the crucial role in decision making. Similarly, in $71 \%$ household decision regarding to family matters are made by both male and female member on the basis of mutual consensus and family level discussions.

\section{Table 9}

Decision Maker in Family

\begin{tabular}{lcc}
\hline Response & Frequency & Percent \\
\hline Male member & 13 & 18.8
\end{tabular}




\begin{tabular}{lcc} 
Female member & 7 & 10.2 \\
Both male and female & 49 & 71.0 \\
\hline Total & 69 & 100.0 \\
\hline
\end{tabular}

Note. Data are collected from online survey, 2020.

Table10 depicts the profile of members who does the household chores. This study shows that out of 69 households $1.4 \%$ male member perform the household chores where as in 47. $8 \%$ household female members do the household activities of caring and nurturing functions. Similarly, in $50.7 \%$ household both male and female members do the household chores.

\section{Table 10}

Who Does Household Chores?

\begin{tabular}{lcc}
\hline Response & Frequency & Percent \\
\hline Male member & 1 & 1.4 \\
female member & 33 & 47.8 \\
both Jointly & 35 & 50.7 \\
\hline Total & 69 & 100.0 \\
\hline
\end{tabular}

Note. Data are taken from online survey 2020.

The table 11 presents the situation of work load in family. The study shows that out of 69 households, women are bearing double burden work in $81.2 \%$ households where as women are taking the single job, either in the public field or in the household level, in $18.8 \%$ household.

\section{Table 11}

\begin{tabular}{lcr}
\multicolumn{3}{l}{ Situation of Double Burden of Working Women } \\
\hline Response & Frequency & Percent \\
\hline Yes & 56 & 81.2 \\
No & 13 & 18.8 \\
\hline Total & 69 & 100.0 \\
\hline
\end{tabular}

Note. Data are taken from online survey 2020. 
The table 12 presents the impact of household chores to the in the work performance in the place of employment. The study shows that $55.1 \%$ opines that household chores affect negatively the work performance in the working place whereas $44.9 \%$ opines that there is no relationship between the household chores and work performance of public sector.

\section{Table 12}

\begin{tabular}{|c|c|c|}
\hline Response & Frequency & Percent \\
\hline Yes & 38 & 55.1 \\
\hline No & 31 & 44.9 \\
\hline Total & 69 & 100.0 \\
\hline
\end{tabular}

Note. Data are taken from online survey 2020

The table 13 presents the situation of conflict created by the women employment in household level. Out of 69 households, there is a conflict created by the women's employment in 10.1 household whereas in $89.1 \%$ household there is no any type of conflict created by the women's employment.

Table 13

Conflict Caused by Women Employment

\begin{tabular}{lcc}
\hline Response & Frequency & Percent \\
\hline Yes & 7 & 10.1 \\
No & 62 & 89.9 \\
\hline Total & 69 & 100.0 \\
\hline
\end{tabular}

Note. Data are taken from online survey 2020.

Table 14 depicts the community attitudes towards the women who are employed or self-employed in community. The study shows that out 69 households, 66.7 percent respondents opines that there is the positive attitude towards the employed or self-employed women where as $4.3 \%$ thinks that there is negative attitude towards working women in community. Similarly $29 \%$ respondents believe that there is moderate type of attitudes towards working women.

\section{Table 14}

Community Attitude Towards Women Employment

Response Frequency Percent




\begin{tabular}{lcc}
\hline Positive attitude & 46 & 66.7 \\
Negative attitude & 3 & 4.3 \\
Moderate & 20 & 29.0 \\
\hline Total & 69 & 100.0 \\
\hline
\end{tabular}

Note. Data are taken from online survey 2020.

Table 15 is related to the experience of working women in work place. Out of 69 respondents $33.3 \%$ respondents assumes that employed and unemployed women are feeling uneasiness in work place. Similarly, $66.7 \%$ respondents think that working women are not feeling uneasiness in their respective work place.

\section{Table 15}

Feeing of Uneasiness in Work Place

\begin{tabular}{lcc}
\hline Response & Frequency & Percent \\
\hline Yes & 23 & 33.3 \\
No & 46 & 66.7 \\
\hline Total & 69 & 100.0 \\
\hline
\end{tabular}

Note. Data are taken from online survey 2020.

Table 16 depicts the increasing rate of socioeconomic status of working women or employed women in community. Out 69 respondents $97.1 \%$ respondents believe that socioeconomic status of working women is increased in community. Similarly, only $2.9 \%$ respondents think that socioeconomic status of working women is not increased in community.

\section{Table 16}

Increment in Socioeconomic Status of Women After Employment

\begin{tabular}{lcc}
\hline Response & Frequency & Percent \\
\hline Yes & 67 & 97.1 \\
No & 2 & 2.9 \\
\hline Total & 69 & 100.0
\end{tabular}

Note. Data are taken from online survey 2020.

Table 17 shows the independency of working women to expend their income as per their interest. Out of 69 respondents $62.3 \%$ respondents believe that working women are free 
to expend their income as per their wish. Likewise, $37.7 \%$ respondents think that working women are not independent to expend their income as per their wish.

Table 17

Situation of leading role of working women in community

\begin{tabular}{lcc}
\hline Response & Frequency & Percent \\
\hline Yes & 48 & 69.6 \\
No & 21 & 30.4 \\
\hline Total & 69 & 100.0 \\
\hline
\end{tabular}

Note. Data are taken from online survey 2020.

\section{Discussion}

Establishment of Gender egalitarian society is the goal of most of feminist theory. If we want to establish this type of society we should give high emphasis on the equal educational and economic opportunities, responsibility in household chores and reformation of social agent who socializes gender based socialization (Lengermann \& Brantely, 2000). The main issue raised in this study was whether working women were playing a dual role in the domestic work and income generating activities. Various indicators were examined in the study to address the determined issue. The findings of this research shows that most of working women have to play a dual role in household chores and income generation work outside from household periphery. However, the status of this double burden varies according to the socio-cultural characteristics. The situation of dual role is different on the basis of caste and ethnicity in Nepali society. Similarly working women have to do all kinds of occupation, even in a professional basis. Working women have a high presence in domestic work within the periphery of the household. In all such households, men and women are seen to be jointly involved in household chores. Similarly, numbers of working women who are involving in domestic works stands in the second position, while this situation is very low in the case of men only.

Working women have to play a dual role or not is also related to their feeling of physical tiredness. Almost all working women are feeling physically tired due to the double work of inner and outer periphery of household, while the opposite situation is seen in the household with nonworking women. Women employees are hampered by individual, organizational, and societal structures that govern them (Adhikary, 2016). However, there is the good support of male members in the household chores in a family with working women. Another indicator that determines the status of working women is the role played by their family members in educating their children and caring of member with illness and sickness in the family. When a family members suffered from the disease, those family members who have time are taken to health institutions, while male are second and female member are third to take 
responsibly in the family respectively. This study shows the same situation in households with non-working women. The role of male member and female member in the education of children in the family is also seen as an indication of measuring the double burden of work of working women. The result of this study shows that women play higher role in the education of children in households with working women, followed by households where women and men play an equal role and household with only male roles respectively.

The second issue raised in this study was to describe the socioeconomic status of working women. Various indicators were examined to address the issue of the socioeconomic status of working women. These indicators include family leadership, occupational area of working women, family conflicts due to the women employment, community attitudes towards them, the comfort they have in the workplace, the increase in their socioeconomic status, independency in spending their earned income and decisive role in decision making at the community level.

There is the positive relation between household and public leadership. When they take the leadership in the family or household, they also develop the leadership skill at the community level. This study has revealed the fact that in this patriarchal society, family leadership has gradually shifted from male leadership to joint leadership of both male and female members in society. This condition is seen in urban areas and in nuclear family. In households with non-working women, men's single leadership is in the first place, while women's and men's joint leadership is in the third place. This shows that women's employment outlined the way for their family leadership. Similarly, the decisive role played by working women in making family matter decisions has been measured as a complementary indicator. Both men and women have played a joint role in making decisions on family matters. In this way, the decisive role of women in family level decision making is gradually increasing and the family joint leadership is and the single leadership of men is increasing. Likewise, the situation of familial harmony is measured which is created by the women's employment in the family. The study shows that there is no conflict in the households which is caused by the women's employment. But in some household has family conflict due to the women's employment. The presence of women in the employment sector in urban areas of Nepali society is gradually increasing. In the field of employment, the presence of women is more in the teaching profession. The main reason of choosing this occupation is that it is available in the local areas due to rise of private sector in educational field in the urban sector. Similarly, there is almost the same presence of service sectors which includes banking, civil service, nursing etc.

The social status of working women has also been measured from the community attitude towards employed women in the urban society. "Women's increasing educational attainment and participation in paid employment and men's rising employment instability and increasing involvement ... in domestic work and childcare" (Vidal \& Lerch, 2019, p. 1112). 
This study shows that community has positive attitude towards them. Similarly the number of some cases view that there is a moderate type of community attitudes towards them. Only few number of respondent expressed negative attitudes towards them. Another indicator is whether the socioeconomic status of working women is the main variable to analyze the socioeconomic status of working women. The socioeconomic status of working women has improved due to the women's employment. Women's employment is generating their identity in their respective community and workplace which also helps to the material achievement and positive social attitude towards them (Hanson, 2009). This claim is also supported by the finding of this research. Nearly cent percent respondents have revealed the fact that women employment raised the socioeconomic status of women. Another complementary indicator to measure the socioeconomic status of working women is their freedom to spend the earning earned by them. This indicator shows that about sixty-three percent of respondents believe that women spend their income independently. This fact shows that women's freedom is gradually increasing in urban areas. Another indicator is that whether working women are feeling comfortable or uncomfortable in their workplace being the women. Two thirds of respondents said that they do not have problems in workplace.

\section{Conclusion}

In patriarchal society women are assigned in the job of household chores and male are assigned to the bread winning job. But it is the traditional belief and it has changed. However, the change has various forms on the basis of structural components of society. There is the rapid change in the gender role in urban areas where as it is slower in rural areas. This study has examined the various indicators to explore the dual role played by working women. It includes involvement in the household chores, relaxation time, male involvement in domestic chores, impact of domestic chores on the work performance in workplace, male/female role in educating children, the job of care giving to the sick people in the family etc. The analysis of these indicators shows that gender role and relation is changing in Nepali urban area. Similarly, this change is realized in the urban area and nuclear family. However, the situation of dual role is seen in this study. Working women have to play the role in household chores and they have to perform the breadwinning job also. It shows that they are taking the double burden of work.

Second issue of this study is to describe the changing socioeconomic status of working women in society. Different indicators are observed to describe the socioeconomic status of working women. Situation of leadership in family, occupational area of working women, conflict arise from the women employment, increment of socioeconomic status, feeling of comfort or discomfort in work place, independency in spending their income, community attitudes towards working women, decisive role in decision making at the community level etc. are the major indicators to describe the socioeconomic status of working women in this study. The result obtained in this study shows that the socioeconomic status of working women has 
increase with their occupational post. Similarly, community level, their access is also increased in decision making. Nuclear family structure, rise of modern education, extended and changing role etc. have played important role in increasing gender role in modern society.

\section{References}

Acharya, M. \& Ghimire, P. (2005). Gender indicators of equality, inclusion, and poverty reduction: measuring programme/project effectiveness. Economic and Political Weekly, 40(44-45), 4719-4728. http://www.jstor.com/stable/4417358.

Adhikary, J. (2016). Barriers to career progression: A Study of the perceptions of Nepali women employees. Journal of Business and Management Research, 1(2), 17-32. https://doi.org/10.3126/jbmr.v1i2.15657

Blunch, N. H., \& Das, M. B. (2015). Changing norms about gender inequality in education: evidence from Bangladesh. Demographic Research, 32, 183-218. https://www.jstor.org/stable/10.2307/26350112

Bushell, B. (2008). Women entrepreneurs in Nepal: what prevents them from leading the sector. Gender, Development, and Leadership, 16(3), 549-564. http://www.jstor.com/stable/20461302

Gynawali, . A. (2017). Work-family balance and its outcome among female teachers in Nepal. International Journal of Research in Business Studies and Management, 4 (6), 23-29.

Hanson, S. (2009). Changing places through women's entrepreneurship. Economic Geography, 85(3), 245-267. http://www.jstor.com/stable/40377305

Jackson, S. (1998). Theorizing gender and sexuality. In S. Jackson and J. Jones (Eds.), Contemporary Feminist Theories,131-146. Edinburgh University Press. http://www.jstor.com/stable/10.3366/j.ctvxcrxc7.12

Johson, D. P. (2008). Contemporary Sociological Theory: An Integrated Multi-level Approach. Springer Publication.

Khan, T., \& Khan, R. E. (2009). Urban informal sector: how much women are struggling for family survival. The Pakistan Development Review, 48(1), 67-95. http://www.jstor.com/stable/41260908

Lengemann, P. M. \& Branthey, J. N. (2000). Contemporary feminist theory. In G. Ritzer, Sociological theory, 443-489. Mac Graw Hill.

Macionis, J. J., \& Plummer, K. (2014). Sociology: A global introduction (5 $5^{\text {th }}$ edition). Pearson.

Moaddel, M. (2020). The status of women and gender equality. In M. Moaddel (Ed.), The clash of values: Islamic fundamentalism versus liberal nationalism, 59-62. Columbia University Press. http://www.jstor.com/stable/10.7312/moad19382.6 
Mogford, E., Courtney, A.I, \& Das, A. (2015). Change gender: combating hegemonic masculinity through antiviolence activism in northern India. International Journal of Sociology of the Family.2, 71-93. http://www.jstor.com/stable/44507290

O'Conner, P. (2007). Still changing places: women's paid employment and gender Roles. The Irish Review (Cork), 35, 64-78. http://www.jstor.com/stable/29736320

Schaefer, R. T. (2006). Sociology: A Brief Introduction (6 $6^{\text {th }}$ edition). TATA McGRAW-Hill.

Singh-Sengupta, S. (2006). Gender, work, and organizational culture: a southeast Asian experience. Indian Journal of Industrial Relations,41(4), 304-328. http://www.jstor.com/stable/27768036

Vidal, S \& Lersch, P. M. (2019). Changes in gender role attitudes following couples' residential relocations. Demographic Research. 40, 1111-1152. http://www.jstor.com/stable/26727028

Warren, A. C. (2010). Women's employment and changing gender relations in Puerto Rico. Caribbean Studies, 38(2), 59-91. http://www.jstor.com/stable/41220536 